Syntax Idea: p-ISSN: 2684-6853 e-ISSN: 2684-883X

Vol. 3, No. 12, Desember 2021

\title{
MASA DEPAN KERJA SAMA SELATAN-SELATAN: DIANTARA SOLIDARITAS DAN KEPENTINGAN
}

\section{Bunga Putri Nauli}

Universitas Indonesia (UI) Depok Jawa Barat, Indonesia

Email: bunga.putri91@ui.ac.id

\begin{abstract}
Abstrak
Fenomena tahun 1950-1970an memperlihatkan bahwa bantuan material, financial, dan technical telah diberikan antar negara berkembang. Kerja Sama Selatan-Selatan (KSS) merupakan salah satu modalitas kerja sama pembangunan internasional antar negara berkembang untuk saling membantu melalui mekanisme saling belajar, berbagi pengalaman, serta alih teknologi guna mencapai kesejahteraan bersama. Pola kerja sama yang bersifat demand-driven membedakan KSS dari kerja sama lainnya sehingga dianggap lebih berprospek. Tidak ada pendekatan one-size-fits-all dalam KSS tetapi disesuaikan dengan kebutuhan negara mitra. Seiring berjalannya waktu, KSS tidak lagi terbatas dalam konteks Asia-Afrika dan merupakan suatu kerja sama yang berprogres. Dengan menggunakan metode kualitatif deskriptif dan kerangka analisis rezim internasional, tujuan penelitian ini adalah melihat posisi yang harus diambil negara-negara anggota KSS ditengah pola shifting dari tatanan internasional dimana solidaritas dan acting collectively harus tetap ditegakkan. Di tengah berbagai tantangan seperti kebijakan me-first policy, pendekatan bilateral dan regional, new southern policy, no single domination, KSS harus tetap mempertahankan prinsip solidaritasnya.
\end{abstract}

Kata Kunci: Kerja Sama Selatan-Selatan; demand-driven; solidaritas; mutual benefit; shifting

\section{Abstract}

The phenomenon of 1950s-1970s showed that material, financial, and technical assistance had been provided between developing countries. South-south cooperation (KSS) is one of the modalities of international development cooperation between developing countries to healp each other through mutual learning, sharing of experiences, and transfer of knowledge mechanisms in order to achieve mutual prosperity. The demand-driven pattern distinguishes SSC from other collaborations so that SSC considered as more prospective approach. There is no one-size-fits-all approach but it based on the needs of partner countries. By the time, SSC is no longer limites to the Asia-Africa context and as a progressive collaboration. By using descriptive qualitative methods and international regimes as an analytical framweork, the aim of this research is to show position that should be taken by SSC members in the middle of shifting of international order in which solidarity and acting collectively must be maintained. In the midst of various challenges such as the me-first policy, bilateral and regional approaches, new southern policy, and no single domination approach, SSC still has to maintain the principle of solidarity. 
Keywords: South-south cooperation; demand-driven; solidarity; mutual benefit; shifting

Received: 2021-11-22; Accepted: 2021-12-05; Published: 2021-12-20

\section{Pendahuluan}

Pada tahun 1950-1970an, terjadi peningkatan sentimen dari negara-negara Selatan pada sistem Bretton Woods yang dianggap lebih bersifat menghambat daripada memfasilitasi pembangunan dan perkembangan ekonomi. Ketika Amerika Serikat memberikan bantuan Marshall Plan pada Eropa, di saat yang bersamaan negara berkembang seperti China, India, Brazil telah memberikan bantuan material, financial, dan technical untuk negara berkembang lain. Peningkatan sentimen tersebut memunculkan istilah 'the decline of the west dan 'the rise of the rest' (Trinidad, 2014) Negara dunia ketiga yang mayoritasnya baru merdeka kemudian menyatakan diri bebas dari pengaruh proxy war, mengadakan konferensi yang diikuti oleh negara Asia dan Afrika.

Pada Konferensi Asia Afrika (KAA) Tahun 1955 tersebut, disepakati Bandung Principle sebagai Final Communiqué KAA yang mana salah satu prinsipnya adalah "memajukan kepentingan bersama dan kerja sama untuk mendukung kedamaian dan kerja sama dunia". Seluruh negara sepakat untuk mendorong kerja sama teknis antar negara sebagai upaya meningkatkan ekonomi di kawasan Asia-Afrika (CVCE, 2017). Kerja Sama Selatan-Selatan (KSS) merupakan salah satu modalitas kerja sama pembangunan internasional antar negara berkembang untuk saling membantu melalui mekanisme saling belajar, berbagi pengalaman, serta alih teknologi guna mencapai kesejahteraan bersama. Kerja sama yang bersifat demand-driven menjadi menarik karena membedakan KSS dari kerja sama lainnya (UN-ESCAP, 2018). KSS dianggap berprospek karena ketiadaan gap technology serta gap pembangunan yang tidak terlalu jauh sehingga akan terjadi keselarasan dengan situasi dan kepentingan negara users (negara penerima bantuan).

Kerja Sama Selatan-Selatan memiliki lima prinsip utama, yaitu menghormati: (1) kedaulatan nasional; (2) kepemilikan nasional dan kemerdekaan; (3) kesetaraan; (4) non-conditional; (5) non-intervensi pada permasalahan domestik; serta (6) mutual benefit. Hingga saat ini, Bandung Principle atau Dasasila Bandung menjadi rujukan pelaksanaan kerja sama pembangunan baik di forum global maupun kerja sama antar negara berkembang, seperti pada Forum UN Conference on South-South Cooperation yang menghasilkan Buenos Aires Plan of Action (BAPA+40) dan Pencapaian Agenda 2030 of Sustainable Development khususnya SDGs Tujuan 17 (About South-South and Triangular Cooperation, 2020).

KSS telah memperkuat kapasitas produktif negara-negara berkembang terutama melalui peningkatan investasi dan perdagangan. Aliran investasi ke negara berkembang yang mencapai tingkat tertinggi dari US\$759 miliar pada 2013, menyumbang 52\% dari arus masuk FDI global. Negara berkembang memberikan $33 \%$ dari investasi global, 
naik 13\% dari tahun 2007. Dari 1980-2008, perdagangan Utara-Selatan meningkat enam kali lipat sementara Perdagangan Selatan-Selatan meningkat sepuluh kali lipat (Centre for Policy Dialogue, 2015). World Bank memproyeksikan negara berkembang akan menyumbang lebih dari setengah total capital stock pada tahun 2030. FDI yang keluar dari negara berkembang ke negara berkembang lainnya tumbuh dua pertiga, dari $\$ 1,7$ triliun pada 2009 menjadi US\$2,9 triliun pada 2013. Proyek infrastruktur menyumbang sekitar 55\% dari KSS dan lebih dari sepertiga negara KSS mendukung sektor sosial (UNDP, 2016). Selama rentang tahun 1995-2008, persentase rata-rata KSS di wilayah Selatan meliputi: 1) 4,2 \% di Amerika Latin dan Karibia; 2) 3,1\% di Afrika; 3) 4,5\% di Timur Tengah; serta 4) 27,8\% dengan Developing Asia (Thorsteinsdottir, 2012).

Kerja Sama Selatan-Selatan bukannya berjalan tanpa tantangan. Tantangan bagi negara-negara dapat dilihat berdasarkan dua perspektif. Pertama, tantangan yang dirasakan baik oleh providers (negara pemberi bantuan) maupun oleh users (negara penerima bantuan) KSS. Dari sisi providers diantaranya: a. kurangnya kerangka institusional dan hukum nasional (meliputi kerangka hukum nasional, keberlanjutan program KSS domestik, institusionalisasi KSS, panjangnya proses pengambilan keputusan domestik dalam memasukkan inisiatif atau praktik terbaik, dan pemilihan focal point yang sesuai); b. terbatasnya koordinasi dan knowledge-sharing (yang meliputi keterlibatan negara-negara penerima, koordinasi internal, peran yang relevan dan terkoordinasi dari organisasi antar pemerintah termasuk sistem PBB, manajemen pengetahuan/berbagi informasi di antara badan dan entitas kerjasama pembangunan untuk menghindari duplikasi); c. terbatasnya measurement (meliputi pengukuran sistematis dan efektif atas keberhasilan KSS dan kurangnya statistik dan data yang dapat diandalkan secara nasional dan internasional); serta d. dana yang tidak mencukupi (Unctad, 2019).

Dari sisi users, tantangan yang dialami meliputi: a. terbatasnya informasi tentang bantuan teknis dan pengembangan kapasitas manusia; b. transfer teknologi yang tidak memadai; c. terbatasnya akses ke financial resources; serta d. kurangnya measurement dan ketersediaan data (UN-ESCAP, 2018). Selain itu, kritik yang muncul pada KSS adalah keterlibatan triangular mengingat sifat politik bantuan asing dan persyaratan dari kelembagaan. Skema ini memperlihatkan ketidakinginan untuk melepas pengaruh dan menjadi bayang-bayang dalam upaya kemandirian yang dilakukan oleh KSS. Keberadaan triangular akan mempertanyakan posisi KSS sebagai alternatif dari Kerja Sama Utara-Selatan yang menekankan pada dependensi. Diperlukan analisis lanjutan untuk menganalisasi apakah kerjasama triangular memiliki potensi berdampak pada tiga isu, yaitu: 1) kepentingan nasional, 2) dampak pembangunan, dan 3) kepemilikan (Sato, 2018). Kedua, dari sisi tatanan global, tantangan yang muncul terkait dengan shifting pada tatanan internasional dengan berbagai fenomena seperti: 1) Me-First Policy; 2) pendekatan bilateralisme dan regional; 3) New Southern Policy; dan 4) shifting to no single domination.

Periode tahun 2014-2019 menjadi periode penting untuk melihat perkembangan KSS selama 5 tahun terakhir. Maka, penelitian ini akan berfokus melihat bagaimana 
KSS tetap dapat bertahan dari tantangan-tantangan yang terjadi dengan menggunakan pendekatan rezim internasional. Penelitian ini mencoba untuk melihat bagaimana KSS dapat bertahan sebagai institusi demand $ר$-driven ditengah shifting pada perubahan tatanan internasional dalam melihat gambaran bahwa KSS dapat bertahan sebagai terobosan baru atas kerja sama yang bersifat demand-driven yang bergerak sesuai dengan permintaan users. Secara spesifik, pertama, mengidentifikasi shifting yang berdampak pada perubahan tatanan internasional. Kedua, melihat poin-poin penting agar KSS dapat bertahan.

Penelitian-penelitian sebelumnya berfungsi dalam membantu analisa penulis dan memperkaya pembahasan penelitian, serta membedakannya dengan penelitian yang sedang dilakukan. Penelitian-penelitian sebelumnya berfokus baik pada optimisme maupun pesimisme dari KSS yang dianggap stagnan. Penulis mencoba untuk mengisi loopholes pada penelitian dengan memasukkan shifting tatanan internasional dan faktorfaktor penting apa yang harus ditekankan KSS untuk tetap bertahan menghadapi shifting tersebut.

\section{Metode Penelitian}

Untuk mencapai tujuan, penulis menggunakan metode kualitatif secara deskriptif dengan metode studi pustaka/dokumen dengan mengumpulkan informasi dari sumber data sekunder seperti laporan pemerintah, jurnal, dan dokumen penunjang lainnya untuk kemudian dianalisis dengan menggunakan variabel-variabel dalam kerangka analisis di atas. Berita-berita relevan mengenai perubahan dalam tatanan global yang terjadi akan memaknai pentingnya masa depan Kerja Sama Selatan-Selatan yang telah dipengaruhi oleh perubahan struktur internasional.

Tulisan ini ditulis dengan struktur sebagai berikut: setelah bagian pendahuluan akan dibahas kajian literatur yang menjadi dasar analisa penulisan, kemudian di bagian ketiga akan dibahas pendekatan rezim institusional dari Krasner. Dibagian keempat akan dibahas modalitas beberapa negara dalam melakukan kerja sama berdasarkan skema KSS dan shifting tatanan internasional yang berdampak pada kerja sama yang telah ada serta bagaimana supaya KSS dapat tetap bertahan disertakan dengan beberapa poin penting. Selanjutnya, kesimpulan akan dibahas sebagai akhir tulisan ini.

\section{Hasil dan Pembahasan}

\section{A. Dinamika dan Masa Depan Kerja Sama Selatan-Selatan}

Istilah South mengacu pada negara-negara berkembang yang berada di Southern Hemisphere, meliputi Asia (kecuali Jepang, Hong Kong, Makau, Singapura, Korea Selatan, dan Taiwan), Amerika Tengah, Amerika Selatan, Meksiko, Afrika, dan Timur Tengah (kecuali Israel) (About South-South and Triangular Cooperation, 2020). KSS bukan hanya pertukaran dari suatu negara ke negara lain. Namun juga termasuk kerja sama mencari solusi kolektif dengan negara berkembang lain, khususnya melalui inisiatif bersama negara-negara tetangga dan mekanisme regional (UN-ESCAP, 2018). 
Modalitas dan geografi merupakan faktor utama yang menentukan dalam Kerja Sama Selatan-Selatan. Modalitas termasuk pendanaan dan bantuan teknis (in-kind assistance) yang memiliki tujuan untuk pengembangan manusia dan kapasitas kelembagaan. China, India, Indonesia, Iran, dan Thailand memberikan dukungan keuangan kepada mitra Selatan mereka yang disalurkan baik melalui bilateral maupun bekerja sama dengan badan internasional. Berikut ini adalah gambaran umum modalitas beberapa negara dalam kerangka KSS. Ide intinya adalah best practices dan lessons dengan negara mitra sehingga tidak ada pendekatan one-sizefits-all tetapi disesuaikan dengan kebutuhan negara mitra (UN-ESCAP, 2018). Contoh implementasi modalitas beberapa negara dalam kerangka KSS dapat digambarkan pada bagan berikut:

\begin{tabular}{|c|c|c|c|c|}
\hline Negara & $\begin{array}{c}\text { Modalitas untuk } \\
\text { Menyediakan/Menerima } \\
\text { KSS }\end{array}$ & Bidang Prioritas & $\begin{array}{c}\text { Wilayah/Negara } \\
\text { Prioritas }\end{array}$ & $\begin{array}{c}\text { Total } \\
\text { Kontribusi } \\
\text { Tahunan (5 } \\
\text { thn terakhir) }\end{array}$ \\
\hline Bangladesh & $\begin{array}{l}\text { Experts/knowledge, } \\
\text { Training, Advisory } \\
\text { Services, Study Visits, } \\
\text { Technology Transfer }\end{array}$ & $\begin{array}{l}\text { Rural } \\
\text { Development, } \\
\text { Agriculture/Food } \\
\text { Security, Social } \\
\text { Development }\end{array}$ & $\begin{array}{l}\text { Bhutan, Maldives, } \\
\text { Fiji, Nepal, } \\
\text { Kenya, Kamboja, } \\
\text { Uganda }\end{array}$ & $\mathrm{n} / \mathrm{a}$ \\
\hline China & $\begin{array}{l}\text { Financial, } \\
\text { Experts/knowledge, } \\
\text { Training, Advisory } \\
\text { Services, Study Visits, } \\
\text { Technology Transfer }\end{array}$ & $\begin{array}{l}\text { Urban } \\
\text { Development, } \\
\text { Water and } \\
\text { Waste } \\
\text { Management }\end{array}$ & $\begin{array}{l}\text { Asia dan Pasifik } \\
\text { LDCs, LLDCs, } \\
\text { SIDs }\end{array}$ & $\mathrm{n} / \mathrm{a}$ \\
\hline India & $\begin{array}{l}\text { Financial, } \\
\text { Experts/knowledge, } \\
\text { Training, Advisory } \\
\text { Services, Study Visits, } \\
\text { Technology Transfer }\end{array}$ & $\begin{array}{l}\text { Disaster } \\
\text { reduction, } \\
\text { Agriculture, } \\
\text { Trade, } \\
\text { Technology } \\
\text { Transfer }\end{array}$ & $\begin{array}{l}\text { Asia, Afrika, } \\
\text { Amerika Latin }\end{array}$ & $\mathrm{n} / \mathrm{a}$ \\
\hline Indonesia & $\begin{array}{l}\text { Experts/knowledge, } \\
\text { Training, Advisory } \\
\text { Services, Study Visits, } \\
\text { Technology Transfer }\end{array}$ & $\begin{array}{l}\text { Experts/ } \\
\text { Knowledge } \\
\text { Training } \\
\text { Advisory } \\
\text { Services, Study } \\
\text { Visits }\end{array}$ & $\begin{array}{lr}\text { Fiji, } & \text { Papua } \\
\text { Nugini, } & \text { Timor } \\
\text { Leste, } & \text { Filipina, } \\
\text { Vietnam } & \end{array}$ & $3,588,249.00$ \\
\hline Iran & $\begin{array}{l}\text { Financial, } \\
\text { Services, } \\
\text { Transfer }\end{array}$ & $\begin{array}{l}\text { Finance, Security, } \\
\text { Environment and } \\
\text { Climate Change }\end{array}$ & $\begin{array}{l}\text { Afrika, Irak, } \\
\text { Lebanon, } \\
\text { Afghanistan, } \\
\text { Syria }\end{array}$ & $\mathrm{n} / \mathrm{a}$ \\
\hline Thailand & $\begin{array}{l}\text { Financial, } \\
\text { Experts/knowledge, } \\
\text { Training, } \quad \text { Advisory } \\
\text { Services, Study Visits, }\end{array}$ & $\begin{array}{l}\text { Health, } \\
\text { Community } \\
\text { Development, } \\
\text { Gender }\end{array}$ & $\begin{array}{l}\text { Laos, Myanmar, } \\
\text { Kamboja, } \\
\text { Vietnam, } \\
\text { Indonesia, Sri }\end{array}$ & $\begin{array}{l}500,636,838 . \\
00\end{array}$ \\
\hline
\end{tabular}




\begin{tabular}{|c|c|c|c|c|}
\hline Negara & $\begin{array}{c}\text { Modalitas untuk } \\
\text { Menyediakan/Menerima } \\
\text { KSS }\end{array}$ & Bidang Prioritas & $\begin{array}{c}\text { Wilayah/Negara } \\
\text { Prioritas }\end{array}$ & $\begin{array}{c}\text { Total } \\
\text { Kontribusi } \\
\text { Tahunan (5 } \\
\text { thn terakhir) }\end{array}$ \\
\hline & Technology Transfer & $\begin{array}{l}\text { Women's } \\
\text { development }\end{array}$ & $\begin{array}{l}\text { Lanka, } \\
\text { Bangladesh }\end{array}$ & \\
\hline Vietnam & $\begin{array}{l}\text { Financial, } \\
\text { Experts/knowledge, } \\
\text { Training, Advisory } \\
\text { Services, Study Visits }\end{array}$ & $\begin{array}{l}\text { Statistics, } \\
\text { Macroeconomic } \\
\text { Policies, } \\
\text { Agriculture }\end{array}$ & $\begin{array}{l}\text { Support to: } \\
\text { Aljazair, } \\
\text { Bangladesh, Fiji, } \\
\text { Laos } \\
\text { Support from: } \\
\text { Mexico, Peru }\end{array}$ & $\mathrm{n} / \mathrm{a}$ \\
\hline
\end{tabular}

Sumber: Olahan Penulis dari (UN-ESCAP, 2018)

Di sisi lain, shifting dalam tatanan internasional akan berpengaruh pada kerja sama yang telah ada. Alasannya, kerja sama yang sedang berjalan merupakan bagian integral untuk memastikan perdamaian, stabilitas, dan kemakmuran bagi setiap negara termasuk negara berkembang dan dunia. Bagaimanapun, semua negara memiliki tugas untuk berkontribusi pada ekspansi keseimbangan ekonomi dunia. Faktanya, kemakmuran dari komunitas internasional secara keseluruhan berdampak pada kemakmuran pada konstituennya (Sornarajah \& Wang, 2010). Adapun shifting yang dimaksud oleh penulis meliputi:

\section{B. Me-First Policy}

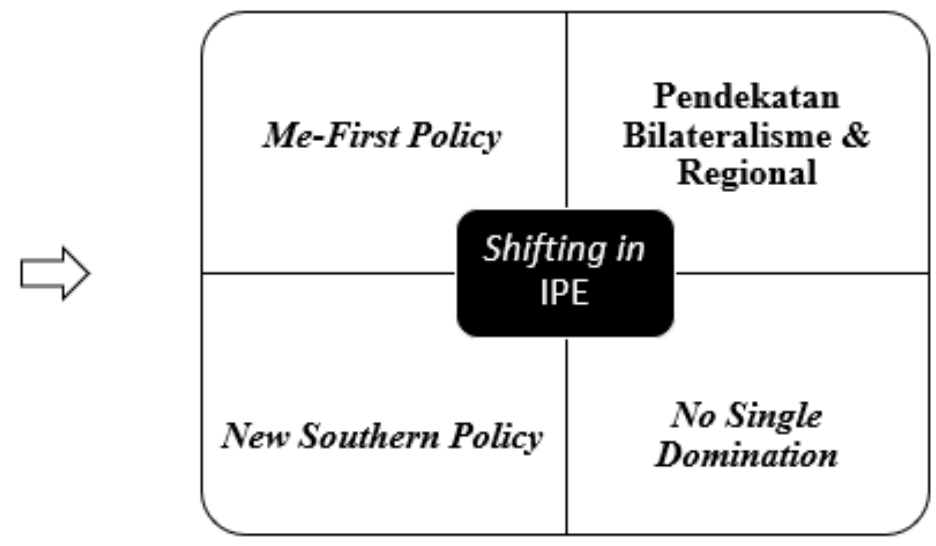

Sumber: Olahan Penulis

Tatanan internasional pasca Perang Dunia-II berada di bawah ancaman dari apa yang disebut dengan Me-First Policy. Nilai-nilai multilateralisme yang telah tumbuh pesat sejak akhir Perang Dunia-II berada di bawah tekanan luar biasa (The Jakarta Post, 2019). Istilah Me-First Policy kembali muncul setelah Donald Trump memperkenalkan bergulirnya kembali proteksionisme. Negara-negara cenderung untuk tidak bekerja sama dan mengarah pada proteksionisme atau unilateralisme. Hal tersebut dipicu oleh positioning Amerika Serikat sebagai negara superpower yang 
mementingkan kepentingannya sendiri. Slogal 'Make America Great Again' menjadi sebuah refleksi bahwa tren Amerika Serikat dibawah Trump akan memprioritaskan kebijakan America-First berdasarkan analogi 'us vs them'. Trump merasa Amerika Serikat berkontribusi terlalu besar sehingga negara superpower tersebut enggan memainkan peran (Döner, 2019). Dunia saat ini menghadapi perubahan terhadap multilateralisme yang 'lemah'. Lemah karena Amerika Serikat memilih untuk tidak memainkan peran yang signifikan.

Kebijakan retaliasi atas proteksionisme Amerika Serikat akan mengarah pada kerusakan ekonomi secara substansial (Felbermayr, Steininger, \& Yalcin, 2017). Gelombang proteksionisme di masa lalu telah menyebabkan banyak perang dan melukai pertumbuhan, inklusi, serta masyarakat (Donnan, S., Tett, G. \& Fleming, 2016). Pemerintah Trump tidak hanya memfokuskan perhatian pada bidang-bidang yang dirasa memiliki praktek perdagangan yang tidak adil dan dipercaya akan mengganggu perdagangan internasional. Trump mengambil pendekatan yang sebagian besar tidak pandang bulu. Pendekatan semacam itu telah menciptakan suatu kondisi uncertainty terutama bagi sekutu-sekutu AS seperti di Asia Timur. Kondisi uncertainty jika ditambahkan ke dalam kebijakan luar negeri akan memiliki potensi melemahkan aliansi dan melemahkan perluasan kemampuan AS dalam tatanan global (Park \& Stangarone, 2019). Salah satu implikasi dari fenomena ini adalah kekhawatiran bahwa negara-negara dalam sistem dunia bersaing satu sama lain untuk meningkatkan ataupun melindungi posisi mereka (Beržiūnas, 2019).

\section{Pendekatan Bilateralisme \& Regional}

Pada tahun 2017, telah terjadi peningkatan Regional Trade Agreement (RTA) hingga mencapai 445 RTA. Pergeseran pada regionalisme ini telah berlanjut pada diskusi para ekonom, apakah RTA menciptakan 'building blocs' atau 'stumbling blocs' (Sheldon, Chow, \& McGuire, 2018). Beberapa negara lebih memilih strategi perdagangan bilateral atau regional daripada multilateral terkait dengan tiga faktor. Pertama, negara-negara berharap dapat memaksimalkan manfaat melalui first-mover advantages. Artinya, negara berfokus untuk memperoleh keuntungan atas penandatanganan perjanjian dengan mitra dagang sebelum negara pesaing melakukan suatu respon dari kebijakan dalam perjanjian. Kedua, negara-negara dapat berupaya lebih dalam menjamin akses permanen ke pasar tertentu. Dipercaya, mekanisme bilateral maupun regional merupakan cara tercepat dan termudah dalam mencapai tujuan tersebut. Ketiga, perjanjian bilateral dapat dimanfaatkan untuk memfasilitasi reformasi dalam negeri, khususnya pada arena yang tidak tercakup secara multilateral seperti investasi, persaingan, lingkingan, serta standar tenaga kerja (Gupta, 2008).

\section{New Southern Policy}

Shifting ketiga dari dinamika ekonomi-politik internasional dewasa ini ialah munculnya inisiatif perubahan orientasi dari negara yang kemudian memiliki fokus pada negara Selatan salah satunya yaitu kebijakan 'New-Southern Policy' (NSP) ala Korea Selatan. Selama bertahun-tahun kebijakan luar negeri Korea Selatan berfokus 
pada Amerika Serikat, China, Rusia, dan Jepang. Melalui strategi kebijakan baru ini, Korea Selatan berupaya melakukan diversifikasi hubungan luar negerinya seperti pada ASEAN dan India serta mengurangi ketergantungan pada keempat kekuatan utama tersebut (Dhawan, 2020). Presiden Moon Jae-In setelah berkuasa pada tahun 2017 memprakarsai New-Southern Policy untuk mengembangkan hubungan ekonomi dan strategis yang lebih dekat dengan kekuatan dan wilayah lain di Asia Selatan. Strategi kebijakan ini terletak pada transportasi, energi, sumber daya air, dan teknologi informasi (Hernandez, 2018).

Tujuan New-Southern Policy adalah membangun komunitas yang berorientasi pada 3P (Prosperity, People, Peace). Dalam kebijakan NSP, 3P's ini dibentuk dalam sebuah komunitas dari masing-masing poin tersebut. Komunitas Masyarakat (People) ditekankan pada sikap saling pengertian dengan meningkatkan pertukaran. Dalam Komunitas Kemakmuran (Prosperity), kebijakan ini menekankan pada pembangunan fondasi hubungan yang memberikan keuntungan serta berdasarkan kerja sama ekonomi yang berorientasi masa depan. Kemudian dalam mewujudkan Komunitas Perdamaian (Peace), ditekankan pada konstruksi lingkungan yang aman dan damai dengan bekerja sama dalam mewujudkan Semenanjung Korea yang damai dan makmur. Kemudian memperluas kerja sama di bidang pertahanan dan industri pertahanan serta meningkatkan ketahanan yang lebih baik (Presidential Committe on New Southern Policy, 2019).

Keseriusan Presiden Moon Jae In dalam meningkatkan hubungan dengan ASEAN dan India terlihat dari: pertama, Presiden Korea menegaskan hubungannya dengan ASEAN dan India sebagai prioritas kebijakan luar negeri pada masa pemilihan Presiden Korea. Kedua, mengirim utusan khusus Presiden ke negaranegara anggota ASEAN. Ketiga, mengunjungi seluruh negara anggota ASEAN dalam dua tahun. Keempat, Presiden Korea yang kembali mengunjungi Brunei Darussalam setelah 19 tahun. Kelima, menjadi Presiden Korea yang mengunjungi Singapura sejak tahun 2003. Keenam, menjadi Presiden Korea yang kembali mengunjungi Kamboja setelah 10 tahun (Ha \& Ong, 2020).

Korea mengarahkan kebijakan NSP disebabkan adanya peningkatan ketegangan dan tekanan dari negara besar di sekitar Semenanjung Korea akibat dari rivalitas dan kompetisi antara Amerika Serikat dan China yang semakin memanas. Di satu sisi, Korea Selatan khawatir menjadi arena konflik antara Amerika Serikat dan China. Mitra yang memenuhi syarat untuk membentuk kerja sama strategis tersebut adalah ASEAN dan India. Selain memiliki kepentingan yang sama, letak geografis pun tidak terlalu jauh (John, 2020). Kritik pada kebijakan ini adalah Korea Selatan hanya berfokus pada negara-negara dengan ekonomi yang lebih besar seperti Indonesia atau Singapura yang akan menjadi pilihan strategis bagi Korea Selatan. (New Southern Policy, 2019) Memihak Amerika Serikat atau China akan merugikan kepentingan Korea. Akibatnya, Korea mempertahankan posisi ambivalen (Dhawan, 2020). 


\section{E. No Single Domination}

China dikenal sebagai global manufacturer in chief dan Amerika Serikat menerima modal dari China untuk membiayai defisit perdagangannya (Pei, 2018). Pendekatan proteksionisme Trump dapat mempercepat upaya negara-negara yang secara tradisional dekat dengan Amerika Serikat untuk pada akhirnya memperkuat hubungan dengan China (Park \& Stangarone, 2019). Di Asia, proteksionisme Trump membawa China di bawah Xi Jinping melangkah pada bigger world stage. Para analis statistik berargumen bahwa China merupakan negara terbesar di dunia dalam keseimbangan daya beli. Dengan pangsa China dalam perdagangan global, dunia akan bergerak menuju sistem yang lebih multipolar. Periode dominasi Amerika Serikat mulai dari runtuhnya Berlin Wall dan runtuhnya Lehman Brothers diprediksi akan berumur lebih pendek. Trump yang mempercepat perubahan ini (Siddiqui \& Singh, 2021). Peningkatan power China menyajikan tantangan yang unik dan belum pernah terjadi sebelumnya atas tatanan dunia yang didominasi Barat. Para pemimpin China mempercayai bahwa globalisasi perdagangan, keuangan, dan komunikasi telah menghasilkan ekonomi dunia yang lebih kompleks dan saling bergantung. Negaranegara kapitalis tidak lagi mampu mencegah maupun mengendalikan difusi dan redistribusi kekuatan ekonomi dan politik. Hasilnya, mereka percaya tatanan dunia multipolar baru muncul dan sedang terjadi dibentuk oleh negara-negara berkembang yang lebih besar seperti China, Brazil, India, dan Afrika Selatan bersama dengan dukungan negara-negara berkembang lainnya di Global South. KSS secara bertahap muncul dari bayang-bayang yang telah lama menjadi sibling yang telah lama 'diabaikan' dalam kerja sama pembangunan internasional. Selain Afrika, kebijakan penting lainnya datang dari Amerika Latin atas ketidakpuasan rakyat yang disebabkan oleh dampak globalisasi neoliberal dan dekade dominasi neo-kolonial dari Utara (Harris \& Arias, 2016). Shifting-shifting tersebut seharusnya dapat dijadikan momentum peluang dibandingkan dengan tantangan bagi KSS untuk bersikap adaptif dari kemungkinan terjadinya perubahan atas tatanan internasional agar dapat terus bertahan. Selanjutnya, penulis akan menjelaskan faktor yang menyebabkan KSS dapat terus bertahan dikaitkan dengan pendekatan rezim internasional.

South-North Cooperation dan South-South Cooperation merupakan komponen penting dalam kerja sama global. Perbedaannya, terletak pada basis politik, basis ekonomi, unsur internal, serta efek praktiknya.

Prinsip: Jika dikaitkan dengan rezim internasional ala Krasner, agenda dan inisiatif Kerja Sama Selatan-Selatan harus ditentukan oleh negara-negara Selatan, dipandu oleh prinsip-prinsip penghormatan terhadap kesetaraan, kedaulatan nasional, kepemilikan dan kemerdekaan nasional, non-conditionality, non-interference dalam urusan domestik serta mutual benefit (About South-South and Triangular Cooperation, 2020). Capacity Development: Kerja sama teknis cenderung sangat berfokus pada pengembangan kapasitas yang bertentangan dengan 'produk'. Kerja 
sama ini bersifat embedded sebagai alat untuk saling belajar (Partners in Population and Development, 2018).

- Kemitraan horizontal: KSS menawarkan hubungan berbeda yang dapat meningkatkan keragaman teknis di tingkat negara dan regional serta menciptakan bentuk kemitraan pembangunan yang lebih horizontal karena luasnya pilihan dukungan (Partners in Population and Development, 2018).

- Adaptability: Atas dasar providers dan users berbagi informasi, kerja sama ini dapat memberikan solusi yang relevan dengan keadaan dan kebutuhan (Development, 2018).

Norma: Munculnya KSS telah mengubah norma kerja sama pembangunan. Hierarkhi antara hubungan donor dengan penerima di masa lalu telah memberi jalan yang lebih inklusif atas kemitraan yang setara. Pendekatan kerja sama pembangunan mencerminkan standar dan norma serta prioritas KSS untuk berbagi pengalaman sukses dengan negara lain (Tasker, 2018).

Aturan : Minimum Common Denominator - Mitra dalam KSS mencoba untuk menyelaraskan pelaporan dasar khususnya seputar kerja sama teknis (UNCTAD, 2019).

Prosedur Pengambilan Keputusan: Karakter yang didorong oleh demanddriven. Hubungan yang horizontal membuat KSS lebih selaras dalam hal prioritas dan kebutuhan. Keputusan untuk melakukan kerja sama memperhatikan asas kebutuhan dan permintaan (Development, 2018).

Selaras dengan pemikiran Grieco, rezim dalam hal ini KSS dapat menjadi sarana negara untuk menciptakan keseimbangan distribusi keuntungan dari kerja sama. Khususnya bagi KSS yang didasarkan pada kerja sama demand-driven. Sejak didasarkan pada faktor historis, KSS menjadi pemandu bagi interaksi antar negara dalam membina kerja sama atas dasar kepentingan bersama. KSS pun memiliki pengaruh dari konstruktivisme karena memutuskan untuk bekerja sama sejak memiliki faktor historis dan identitas yang dibangun bersama sejak pertemuan di Bandung pada tahun 1955 (Tarzi, 2003). Solidaritas yang diusung KSS memang menjadi dilema jika dikaitkan dengan kepentingan nasional (Gray \& Gills, 2016). Dalam praktiknya, kepentingan nasional tampaknya menjadi perhatian dominan negara-negara yang mempengaruhi perdagangan (Engel, 2019). Solidaritas merupakan komitmen untuk saling mendukung upaya bersama dalam mencapai pembangunan yang berkelanjutan dan integral. Namun, pemerintah juga membedakan pendekatan terhadap KSS antara domensi komersial tentang kepentingan pembangunan sosial ekonomi dalam teritori mereka (kepentingan nasional) dan kerja sama dengan azas mengutamakan kepentingan umum (donor, hibah, atau sejenisnya) untuk kepentingan pengembangan masyarakat mitra (Gray \& Gills, 2016).

Juga, terdapat beberapa catatan penting agar KSS tetap dapat bertahan meskipun memiliki tantangan perubahan tatanan global. Pertama, pembentukan tatanan ekonomi internasional yang berlaku didasarkan pada kekuatan ekonomi. 
Perjuangan dari negara-negara ini untuk New International Economic Order (NIEO) tidak dapat mengandalkan negara manapun. Semakin kuat kekuatan ekonomi, semakin meningkat kemampuan untuk mempengaruhi pembuatan keputusan ekonomi dunia. Bagaimanapun, negara-negara berkembang harus memberdayakan diri mereka sendiri. Kedua, sejarah menunjukkan bahwa ketergantungan ekonomi yang berlebihan pada negara maju tidak menguntungkan bagi perkembangan ekonomi nasional negara berkembang. Tindakan yang tepat untuk meningkatkan kekuatan ekonomi adalah dengan meningkatkan KSS dengan kemandirian kolektif untuk membangun ekonomi nasional yang mandiri serta mengurangi bahkan jika dimungkinkan meniadakan ketergantungan pada negara maju (Sornarajah \& Wang, 2010).

Ketiga, KSS dapat mengumpulkan kekuatan negara-negara dunia ketiga yang tersebar secara individual dan secara ekonomi lemah. Kekuatan ini dapat meningkatkan status negara dunia ketiga dalam dialog dan negosiasi antara UtaraSelatan. Keempat, KSS merupakan tipe baru hubungan ekonomi internasional dengan dasar hubungan timbal balik. Akan terdapat pembelajaran untuk mengutamakan saling menguntungkan untuk kemajuan dan pengembangan bersama. Melalui hal tersebut, KSS dapat dibawa ke dalam fase baru yang lebih berprospek. Kelima, KSS tidak bertujuan untuk memisahkan hubungan dengan negara maju atau menggantikan hubungan Utara-Selatan. KSS mempromosikan perbaikan hubungan Utara-Selatan dengan meningkatkan kerja sama ekonomi Utara-Selatan didasarkan pada basis equity dan mutual benefit. maka, solidaritas dan acting collectively harus tetap ditegakkan. Dengan harapan untuk merealisasikan kemakmuran yang berlaku umum bagi semua negara (Sornarajah \& Wang, 2010). Keenam, KSS harus memberikan sistem bantuan yang lebih termonitor untuk meningkatkan koordinasi antar negara. Maka, pendekatan demand-driven dapat diperkuat dengan adanya sistem yang akuntabel dan mumpuni (De Renzio \& Seifert, 2014). Kekurangan sistem demand-driven terkait dengan sustainability. Perubahan kepemimpinan akan mempengaruhi berbagai orientasi kebijakan dan prioritas yang akan merubah, mempengaruhi, dan membentuk kebijakan negara (Gosovic, 2016).

\section{Kesimpulan}

Kerja Sama Selatan-Selatan menekankan pada aspek berbagi pengalaman dan alih teknologi antar negara berkembang. Sifat demand-driven memberikan keunikan bagi KSS. Selain itu, ketiadaan gap technology serta gap pembangunan yang tidak terlalu jauh membuat KSS dianggap kerja sama yang berprospek. Sejak tahun 1980-2008, perdagangan antar negara Selatan meningkat sepuluh kali lipat sedangkan perdagangan Utara-Selatan meningkat enam kali lipat. Namun, KSS bukannya tanpa tantangan. Tantangan muncul dari negara pemberi dan penerima bantuan. Perubahan kepemimpinan juga akan mempengaruhi berbagai orientasi yang dapat mengubah kebijakan negara Selatan. Selanjutnya, dari sisi tatanan global, tantangan dapat muncul terkait shifting dalam tatanan internasional melalui Me-First Policy, pendekatan 
bilateralisme dan regional, New Southern Policy, dan shifting to no single domination. Kritik juga muncul atas keterlibatan mitra triangular pada KSS. Solidaritas yang diusung KSS memang menjadi dilema jika dikaitkan dengan kepentingan nasional Shifting dalam tatanan internasional akan berpengaruh karena semua negara memiliki tugas untuk berkontribusi pada ekspansi keseimbangan ekonomi dunia. Penulis memberikan catatan agar KSS dapat bertahan meskipun terjadi shifting pada tatanan internasional.

Menurut penulis, sistem ekonomi politik internasional bersifat dinamis yang memungkinkan perubahan hari demi hari. Diperlukan usaha-usaha baru dari negara untuk memenuhi tantangan yang mereka hadapi. Begitu pun dengan KSS. KSS harus dapat memanfaatkan potensi dan prinsip yang telah dimiliki untuk ditegakkan lebih lanjut. Untuk dapat adaptive di masa depan, KSS harus mengembangkan mekanisme kerja sama melalui platform yang transparan. Tidak ada jalan untuk kembali ke masa lalu tetapi potensi yang ada harus dimaksimalkan dalam jangkauan kita untuk masa depan. Perjalanan tersebut harus ditempuh bersama-sama dalam kemitraan negara. Harapannya, potensi penuh, kepercayaan diri dan perasaan empati satu sama lain membuat negara-negara Selatan mampu mencapai arti solidaritas sesungguhnya untuk memainkan peranan yang lebih signifikan dalam tatanan global. 


\section{BIBLIOGRAFI}

About South-South and Triangular Cooperation. (2020). Retrieved from https://www.unescap.org/blog/promoting-south-south-cooperation-asia-and-thepacific UNOSSC.

Beržiūnas, Valentinas. (2019). Donald Trump's International Economic Policy from the World System's Perspective. Lithuanian Annual Strategic Review, 17, 63-95. Google Scholar

Centre for Policy Dialogue. (2015). Deconstructing South-South Cooperation: A Southern Perspective on Experience and Challenges. National Council of Applied Economic Research.

De Renzio, Paolo, \& Seifert, Jurek. (2014). South-South cooperation and the future of development assistance: mapping actors and options. Third World Quarterly, 35(10), 1860-1875. Google Scholar

Development, Partners in Population and. (2018). Overview of South South Cooperation. Retrieved from http://partners-popdev.org/docs/PPD_SouthSouth_Book.pdf.

Dhawan, Ranjit Kumar. (2020). Korea's 'New Southern Policy'Towards India: An Analysis. Jadavpur Journal of International Relations, 24(1), 53-72. Google Scholar

Döner, Fatma Nil. (2019). Trump's Wisdom for the International Political Economy: A Way to Collective Carnage? Perceptions: Journal of International Affairs, 24(1), 105-130. Google Scholar

Donnan, S., Tett, G. \& Fleming, S. (2016). Lagarde Warns Trump-Style Protectionism Would Hit World Economy. Sam FT.

Engel, Susan. (2019). South-South Cooperation in Southeast Asia: From Bandung and Solidarity to Norms and Rivalry. Journal of Current Southeast Asian Affairs, 38(2), 218-242. Google Scholar

Felbermayr, Gabriel, Steininger, Marina, \& Yalcin, Erdal. (2017). Quantifying Trump: The costs of a protectionist US. CESifo Forum, 18(4), 28-36. München: ifo Institut-Leibniz-Institut für Wirtschaftsforschung an der. Google Scholar

Gosovic, Branislav. (2016). The resurgence of South-South cooperation. Third World Quarterly, 37(4), 733-743. Google Scholar

Gray, Kevin, \& Gills, Barry K. (2016). South-South cooperation and the rise of the Global South. Third World Quarterly, Vol. 37, pp. 557-574. Taylor \& Francis. Google Scholar 
Gupta, Sayantan. (2008). Changing faces of international trade: Multilateralism to regionalism. J. Int'l Com. L. \& Tech., 3, 260. Google Scholar

Ha, H., \& Ong, Glenn. (2020). Assessing the ROK's New Southern Policy towards ASEAN. Singapore: ISEAS Yusof Ishak Institute. Google Scholar

Harris, Richard L., \& Arias, Armando A. (2016). China's south-south cooperation with Latin America and the Caribbean. Journal of Developing Societies, 32(4), 508556. Google Scholar

Hernandez, C. (2018). Strengthening Korea-ASEAN Relations through the New Southern Policy. Discussion Paper in Jeju Forum: Reengineering Peace for Asia. 4-5.

John, Jojin V. (2020). India-South Korea relations under 'Special strategic partnership': 'Act east policy'meets 'New southern policy.' India Quarterly, 76(2), 207-225. Google Scholar

New Southern Policy': Is South Korea Ready for This?. (2019). http://partnerspopdev.org/docs/PPD_South-South_Book.pdf Inn, S. Google Scholar

Park, June, \& Stangarone, Troy. (2019). Trump's America first policy in global and historical perspectives: Implications for US-East Asian trade. Asian Perspective, 43(1), 1-34. Google Scholar

Partners in Population and Development. (2018). Overview of South South Cooperation. Retrieved from http://partners-popdev.org/docs/PPD_South-South_Book.pdf.

Pei, Minxin. (2018). China in Xi's" New Era": A Play for Global Leadership. Journal of Democracy, 29(2), 37-51. Google Scholar

Presidential Committe on New Southern Policy. (2019). New Southern Policy. Retrieved from http://www.nsp.go.kr/eng/policy/policy02Page.do.

Sheldon, Ian M., Chow, Daniel C. K., \& McGuire, William. (2018). Trade liberalization and constraints on moves to protectionism: Multilateralism vs. regionalism. Wiley Online Library. Google Scholar

Siddiqui, Areej Aftab, \& Singh, Parul. (2021). US-China trade war: Impact on chemical exporting firms from India to US. Corporate Governance, (1), 75-84. Google Scholar

Sornarajah, Muthucumaraswamy, \& Wang, Jiangyu. (2010). China, India and the international economic order. Cambridge University Press.

Tarzi, Shah M. (2003). International regimes and international relations theory: Search for synthesis. International Studies, 40(1), 23-39. Google Scholar 
Tasker, B. J. (2018). South-South Cooperation and International Norm Change: Brazil and Venezuela's Development Assistance Programmes, 2005-2016. UCL (University College London). Google Scholar

Thorsteinsdottir, Halla. (2012). South-South collaboration in health biotechnology: growing partnerships amongst developing countries. IDRC, Ottawa, ON, CA. Google Scholar

Trinidad, D. D. (2014). South-South Cooperation in Southeast Asia and the Role of Japan. Japan External Trade Organization: Institute of Developing Economies.

Un-Escap. (2018). South-South Cooperation in Asia and the Pacific - A Brief Overview.

Unctad. (2019). Defining and Quantifying South-South Cooperation - UNCTAD Research Paper. https://unctad.org/en/pages/PublicationWebflyer.aspx?publicationi $\mathrm{d}=2361$ UN-ESCAP, 2018. Promoting South-South Cooperation in Asia and the Pacific.

Copyright holder:

Bunga Putri Nauli (2021)

First publication right:

Syntax Idea

This article is licensed under:

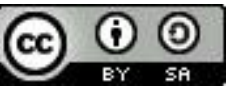

